\title{
Weak $\mathbf{C}-\mathbf{H} \cdots \mathbf{F}-\mathrm{C}$ interactions in carboxylate anion binding: Synthesis, spectroscopic and $\mathrm{X}$-ray structural studies of $\left[\mathrm{Co}(\text { phen })_{2} \mathrm{CO}_{3}\right]_{2}$ $\left(\mathrm{C}_{7} \mathrm{H}_{3} \mathrm{O}_{2} \mathrm{FCl}\right) \mathrm{Cl} \cdot 11 \mathrm{H}_{2} \mathrm{O}$ and $\left[\mathrm{Co}(\text { phen })_{2} \mathrm{CO}_{3}\right]\left(\mathrm{C}_{7} \mathrm{H}_{3} \mathrm{NO}_{4} \mathrm{Cl}\right) \cdot 6 \mathrm{H}_{2} \mathrm{O}$
}

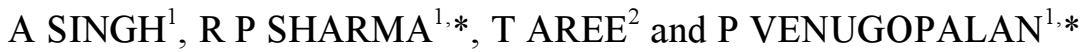 \\ ${ }^{1}$ Department of Chemistry, Panjab University, Chandigarh 160014 \\ ${ }^{2}$ Department of Chemistry, Faculty of Science, Chulalongkorn University, Phyathai Road, \\ Pathumwan, Bangkok 10330, Thailand \\ e-mail: rpsharmapu@yahoo.co.in; venugopalanp@yahoo.com
}

\begin{abstract}
Two new complex salts containing 2,5-substituted benzoate ions, $\left[\mathrm{Co}(\text { phen })_{2} \mathrm{CO}_{3}\right]_{2}$ $\left(\mathrm{C}_{7} \mathrm{H}_{3} \mathrm{O}_{2} \mathrm{FCl}\right) \mathrm{Cl} \cdot 11 \mathrm{H}_{2} \mathrm{O}$ (1) and $\left[\mathrm{Co}(\text { phen })_{2} \mathrm{CO}_{3}\right]\left(\mathrm{C}_{7} \mathrm{H}_{3} \mathrm{NO}_{4} \mathrm{Cl}\right) \cdot 6 \mathrm{H}_{2} \mathrm{O}$ (2) (where phen = 1,10-phenanthroline, $\mathrm{C}_{7} \mathrm{H}_{3} \mathrm{O}_{2} \mathrm{FCl}=2$-chloro-5-fluorobenzoate $(\mathbf{c f b z})$ and $\mathrm{C}_{7} \mathrm{H}_{3} \mathrm{NO}_{4} \mathrm{Cl}=$ 2-chloro-5-nitrobenzoate $(\mathbf{c n b z})$ ) were synthesized by reacting carbonatobis(1,10-phenanthroline)cobalt(III) chloride with appropriate salts in aqueous medium. A detailed packing analysis has been undertaken to delineate the role of second sphere $\mathrm{C}-\mathrm{H} \cdots \mathrm{F}$ and $\mathrm{C}-\mathrm{H} \cdots \mathrm{O}$ interactions amid other heteroatom interactions. The complex salts have been characterized by elemental analyses, spectroscopic studies (IR, UV/Visible, multinuclear NMR), conductance and solubility product measurements. Single crystal X-ray structure determination revealed ionic structures of both the complex salts having discrete ions along with lattice water molecules. Crystal lattice is stabilized by a variety of hydrogen bonding interactions, i.e. $\mathrm{O}-\mathrm{H} \cdots \mathrm{O}, \mathrm{C}-\mathrm{H} \cdots \mathrm{O}$ and $\mathrm{C}-\mathrm{H} \cdots \mathrm{F}$ involving second sphere coordination besides $\pi-\pi$ interaction. Furthermore, packing analyses reveal that $\mathrm{C}-\mathrm{H}{ }^{\cdots} \mathrm{F}$ interactions can manifest even in the presence of a large number of heteroatom interactions.
\end{abstract}

Keywords. Cobalt(III); second sphere coordination chemistry; 1,10-phenanthroline; 2-chloro-5-fluorobenzoate; $\mathrm{C}-\mathrm{H}$...F interactions.

\section{Introduction}

Fluorinated organic compounds have been known for their fascinating properties as fluorine can impart significant effect on their properties such as increased chemical/metabolic stability, lipophilicity, solubility, dipole-dipole and hydrogen bonding interactions. As a result, they have number of applications: (i) about $20-25 \%$ of drugs in pharmaceuticals contain at least one fluorine atom in their molecules, (ii) fluorine substitution is commonly used in medicinal chemistry to improve the metabolic stability, bioavailability and protein-ligand interactions ${ }^{1}$ and (iii) fluorine labelling is employed as an approach for the analysis of secondary structure of RNA. ${ }^{2}$ More recently, the use of fluorinated compounds in 'self disproportion of enantiomers' of increased magnitude has been reported and it is believed that fluorine containing substances may hold great potential in facilitating the study and further practical applications in self disproportion of

\footnotetext{
*For correspondence
}

enantiomers. $^{3,4}$ In all this, the other interesting aspect is that how the fluorinated molecules are self assembled in the solid state leading to minimum energy (or at least low energy) ensembles in the shallow regions of lattice energy surfaces. The role of non-covalent $\mathrm{C}-\mathrm{H} \cdots \mathrm{F}$ and $\mathrm{F} \cdots \mathrm{F}$ interactions immediately warrants consideration, but their role in lattice stabilization has elicited immense importance and debate.$^{5-8}$ Earlier view about organic fluorine is that it hardly involves in the hydrogen bonding and does not contribute to the crystal packing. ${ }^{9,10}$ But Shimoni and Glusker, however, pointed out that although $\mathrm{C}-\mathrm{H} \cdots \mathrm{F}-\mathrm{C}$ interactions are weak as compared to the $\mathrm{C}-\mathrm{H} \cdots \mathrm{O}-\mathrm{H}$ interactions, their contribution in determining the modes of molecular packing in fluorinated complexes and in crystals cannot be overlooked. ${ }^{11}$ Recent investigations have also augmented this point of view. ${ }^{12-16}$ It was observed that when two fragments involved in the interactions are neutral, $\mathrm{C}-\mathrm{H} \cdots \mathrm{F}$ interactions behave as weak hydrogen bonds with interaction energy around $-0.4 \mathrm{kcal} \mathrm{mol}^{-1} .{ }^{17}$

In this backdrop it is worth mentioning that we have undertaken an extensive research programme to 
exploit cationic cobalt(III) complex, $\left[\mathrm{Co}(\text { phen })_{2} \mathrm{CO}_{3}\right]^{+}$ as anion receptors. ${ }^{18-22}$ and the detailed packing analyses of the complexes formed by this cation show that the role of the oxygen atoms of the carbonato group (hydrogen bond acceptor) and the hydrogen atom of the 1,10-phenanthroline moiety (C-H donor) is complementary towards lattice stabilization. Considering such a cohesive behaviour, our recent investigation on $\left[\mathrm{Co}(\text { phen })_{2} \mathrm{CO}_{3}\right]$ (pentafluorobenzoate) $6 \mathrm{H}_{2} \mathrm{O}^{22}$ clearly demonstrated that other than the individual strength of $\mathrm{C}-\mathrm{H} \cdots \mathrm{F}$ interactions, their cooperative contribution is substantial in lattice stabilization. The use of pentafluorobenzoate as a counter anion with a relative high $\mathrm{F} / \mathrm{C}$ ratio could furnish evidence regarding the role of $\mathrm{C}-\mathrm{H} \cdots \mathrm{F}$ interactions especially in the absence of other strong intermolecular forces $(\mathrm{O}-\mathrm{H} \cdots \mathrm{O} / \mathrm{N}$ hydrogen bonding). This led us to an open question: will $\mathrm{C}-\mathrm{H} \ldots \mathrm{F}$ interaction be operative and also play a dominant role when there is other halogen (especially chlorine) present? By now it is well conceived that hydrogen bonding involving heavier halogens $(\mathrm{Cl}, \mathrm{Br}, \mathrm{I})$ is significant in pre-organizing molecules and $\mathrm{C}-\mathrm{H} \cdots \mathrm{X}$ and $\mathrm{X} \cdots \mathrm{X}(\mathrm{X}=\mathrm{Cl}, \mathrm{Br}, \mathrm{I})$ is a well established paradigm for supramolecular synthons in crystal engineering. ${ }^{23-31}$

At this stage, a careful choice of the counter anion becomes essential as we are trying to evaluate molecular events that differ at an energy level less than or equal to $1-2 \mathrm{kcal} / \mathrm{mol}$. The choice of a cation was readily met with $\left.[\mathrm{Co} \text { (phen })_{2} \mathrm{CO}_{3}\right]^{+}$from our previous experience ${ }^{18-22}$ and consideration of the topological features and charge distribution led to the carboxylate anions; 2-chloro-5-fluorobenzoate (cfbz) and 2-chloro-5-nitrobenzoate (cnbz).
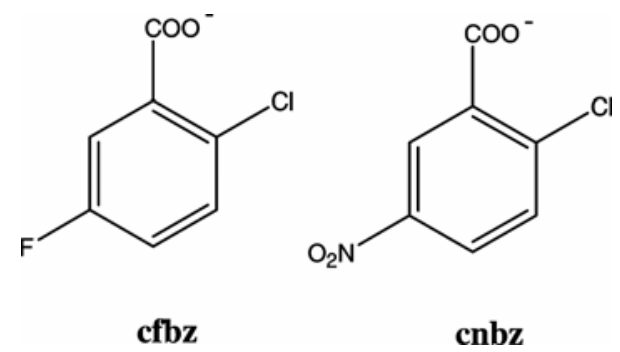

Our choice for these anions were based on the following considerations; (i) Chlorine and fluorine atoms must be as far as away as possible to minimize their interaction interferences in lattice stabilization, (ii) the plane of the carboxylate moiety should deviate to the maximum extent from the molecular plane to minimize the resonance effect with aromatic ring current (larger chloro group rather than fluoro group at ortho position would satisfy this condition), (iii) bromine or iodine is less preferable as the difference in their atomic radii with fluorine is much more pronounced; $\mathbf{c f b z}$ readily satisfies these conditions. The selection of $\mathbf{c n b z}$ also has a purpose: $-\mathrm{NO}_{2}$ is a strong hydrogen bond acceptor group (as it can involve in $\mathrm{C}-\mathrm{H} \cdots \mathrm{O}$ hydrogen bonds) than fluorine and hence replacing fluoro by nitro group may ensue an entirely different interaction pattern in the crystal lattice. Moreover, chlorine is at ortho position in both these compounds; therefore its role through $\mathrm{C}-\mathrm{H} \cdots \mathrm{Cl}$ interaction and its subtle variation can be investigated by detailed packing analyses through X-ray crystallography. This will be an added bonus to the study. Thus, this paper reports the role of weak $\mathrm{C}-\mathrm{H} \ldots \mathrm{F}$ interactions in carboxylate anion binding in the presence of another halogen atom $(\mathrm{Cl})$ and a detailed packing analysis of $\left[\mathrm{Co}(\text { phen })_{2} \mathrm{CO}_{3}\right]_{2}$ $\left(\mathrm{C}_{7} \mathrm{H}_{3} \mathrm{O}_{2} \mathrm{FCl}\right) \mathrm{Cl} \cdot 11 \mathrm{H}_{2} \mathrm{O}$ (1) and $\left[\mathrm{Co}(\text { phen })_{2} \mathrm{CO}_{3}\right]$ $\left(\mathrm{C}_{7} \mathrm{H}_{3} \mathrm{NO}_{4} \mathrm{Cl}\right) \cdot 6 \mathrm{H}_{2} \mathrm{O}$ (2). To the best of our knowledge this is the first crystal structure report of any salt containing 2-chloro-5-fluorobenzoate anion.

\section{Experimental}

\subsection{Materials and measurements}

Analytical grade reagents were used without any further purification $\left[\mathrm{Co}(\mathrm{phen})_{2} \mathrm{CO}_{3}\right] \mathrm{Cl} \cdot 5 \mathrm{H}_{2} \mathrm{O}$ has been prepared by the reaction between $\mathrm{CoCl}_{2} \cdot 6 \mathrm{H}_{2} \mathrm{O}$, 1,10-phenanthroline and sodium bicarbonate. ${ }^{32} \mathrm{C}, \mathrm{H}$ and $\mathrm{N}$ were estimated micro analytically by automatic PERKIN ELMER $2400 \mathrm{CHN}$ elemental analyser. Cobalt was estimated by volumetric method. ${ }^{33}$ UV/Visible spectra were recorded using HITACHI 330 spectrophotometer in water. Infrared spectra of the title complex salts were recorded using PERKIN ELMER spectrum RX FT-IR system using $\mathrm{KBr}$ pellet. ${ }^{1} \mathrm{H},{ }^{19} \mathrm{~F}$ NMR spectra of title complex salts were run in the solvent $\mathrm{D}_{2} \mathrm{O}$ by using BRUKER AC $400 \mathrm{~F}$ $(400 \mathrm{MHz})$ spectrometer. The chemical shift values are expressed as $\delta$ value ( $\mathrm{ppm})$ down field from tetramethylsilane as an internal standard. In ${ }^{19} \mathrm{~F}$ NMR, chemical shift values are expressed as $\delta$ value (ppm) with respect to $\mathrm{CCl}_{3} \mathrm{~F}$.

\subsection{Synthesis of $\left[\mathrm{Co} \text { (phen) }{ }_{2} \mathrm{CO}_{3}\right]_{2}$ (2-chloro-5- fluorobenzoate) $111 \mathrm{H}_{2} \mathrm{O}$ (1)}

To a $10 \mathrm{~mL}$ solution of $\left[\mathrm{Co}(\text { phen })_{2} \mathrm{CO}_{3}\right] \mathrm{Cl} \cdot 5 \mathrm{H}_{2} \mathrm{O}$ $(0.5 \mathrm{~g}, 0.8 \mathrm{mmol})$ in water, $10 \mathrm{~mL}$ solution of 
sodium salt of 2-chloro-5-fluorobenzoic acid (prepared by the reaction of $0.144 \mathrm{~g},(0.8 \mathrm{mmol})$ of 2 chloro-5-fluorobenzoic acid and $0.033 \mathrm{~g},(0.8 \mathrm{mmol})$ sodium hydroxide in $10 \mathrm{~mL}$ of water) was added. Light pink coloured crystals were obtained after ten days when the reaction mixture was allowed to evaporate slowly at room temperature (Yield: 65\%). The composition was established by elemental analyses; $\left[\mathrm{Co}(\text { phen })_{2} \mathrm{CO}_{3}\right]_{2}$ (2-chloro-5-fluorobenzoate) $\mathrm{Cl} .11 \mathrm{H}_{2} \mathrm{O}$, Found (\%): C, 50.01; H, 4.11; N, 8.18; Co, 8.50. Calculated (\%); C, 50.10; H, 4.17; N, 8.20; Co, 8.64.

\subsection{Synthesis of $\left.[\mathrm{Co} \text { (phen })_{2} \mathrm{CO}_{3}\right]$ (2-chloro-5- nitrobenzoate) $\cdot 6 \mathrm{H}_{2} \mathrm{O}$ (2)}

To a $10 \mathrm{~mL}$ solution of $\left[\mathrm{Co}(\text { phen })_{2} \mathrm{CO}_{3}\right] \mathrm{Cl} \cdot 5 \mathrm{H}_{2} \mathrm{O}$ $(0.5 \mathrm{~g}, 0.8 \mathrm{mmol})$ in water, $10 \mathrm{~mL}$ solution of sodium salt of 2-chloro-5-nitrobenzoic acid (prepared by the reaction of $0.166 \mathrm{~g},(0.8 \mathrm{mmol})$ of 2-chloro-5nitrobenzoic acid and $0.033 \mathrm{~g},(0.8 \mathrm{mmol})$ sodium hydroxide in $10 \mathrm{~mL}$ of water) was added. Light pink coloured crystals started appearing after few hours from the reaction mixture (yield: $80 \%$ ). The composition was established by elemental analyses; $\left[\mathrm{Co}\right.$ (phen) $\left.{ }_{2} \mathrm{CO}_{3}\right]\left(2\right.$-chloro-5-nitrobenzoate) $\cdot 6 \mathrm{H}_{2} \mathrm{O}$,

Found (\%): C, 48.60; H, 3.85; N, 8.76; Co, 7.65. Calculated (\%): C, 48.73; H, 3.93; N, 8.88; Co, 7.84.

\section{$2.4 X$-ray data collection}

The X-ray diffraction data were collected on a Bruker X8 APEX II KAPPA CCD diffractometer (at the Scientific and Technological Research Equipment Centre of Chulalongkorn University) at $298 \mathrm{~K}$ using graphite monochromatized Mo-K $\alpha$ radiation $(\lambda=0.71073 \AA)$. The crystal was positioned at $37.5 \mathrm{~mm}$ from the CCD and the diffraction spots were measured using a counting time of $10 \mathrm{~s}$. Data reduction and multi-scan absorption correction was carried out using the APEX II program suite. ${ }^{34}$ The structures were solved using SHELXS-9 $7^{35}$ and refined using full-matrix least squares with SHELXL-97. ${ }^{35}$ Anisotropic thermal parameters were used for all non-H atoms. The hydrogen atoms of $\mathrm{C}-\mathrm{H}$ groups were riding with isotropic thermal parameters equivalent to 1.2 times those of the atom to which they were attached. Most of the hydrogen atoms of water molecules were located from difference Fourier map and were included in the refinement as riding hydrogen atoms. The residual electronic density was within the expected values. Final R-values together with selected refinement details are given in table 1 .

\section{Results and discussion}

\subsection{Synthesis}

The complex salts 1 and $\mathbf{2}$ were synthesized by reaction of $\left[\mathrm{Co}(\text { phen })_{2}(\mathrm{CO})_{3}\right] \mathrm{Cl} \cdot 5 \mathrm{H}_{2} \mathrm{O}$ and sodium salt of respective acids, i.e. 2-chloro-5-fluorobenzoic acid and 2-chloro-5-nitrobenzoic acid, in 1:1 molar ratio in the aqueous medium (scheme 1). The newly formed complex salts are soluble in water, methanol, ethanol, DMSO and insoluble in acetone. Both the complex salts were not decomposed till $250^{\circ} \mathrm{C}$. The complex salts have been characterized by elemental analyses, spectroscopic studies (IR, UV/Visible, ${ }^{1} \mathrm{H}$ and ${ }^{19} \mathrm{~F}$ NMR), solubility product and conductance measurements. The crystal structure has been unambiguously established by single-crystal X-ray crystallography.

\subsection{Measurements of solubility products}

The solubility product (Ksp) for complex salts $\mathbf{1}$ and 2 were determined as $9.15 \times 10^{-6}$ and $7.39 \times 10^{-5}$ (compared to $9.80 \times 10^{-3}$ of $\left[\mathrm{Co}(\text { phen })_{2} \mathrm{CO}_{3}\right] \mathrm{Cl}$. $5 \mathrm{H}_{2} \mathrm{O}$ ) which indicated that the affinity for binding of cationic complex $\left[\mathrm{Co}(\mathrm{phen})_{2} \mathrm{CO}_{3}\right]^{+}$for 2,5substituted carboxylates is in the order $\mathbf{c f b z}>$ cnbz $>$ Cl. Although nearly thousand-fold and hundred-fold decrease in the solubility products of $\mathbf{1}$ and 2 points towards greater affinity, it is to be mentioned that hydration influences the solubility product, especially in the case of different sizes of concerned ions.

\subsection{Molar conductance measurements}

Molar conductance of complex salts $\mathbf{1}$ and $\mathbf{2}$ were measured in aqueous medium in the concentration range $(0-100) \times 10^{-4} \mathrm{M}$ at $25^{\circ} \mathrm{C}$. The limiting molar conductance at infinite dilution $\left(\Lambda_{\circ}\right)$ was obtained by plotting the square root of concentration versus molar conductance and extrapolating concentration to zero. The $\Lambda_{0}$ obtained for salts 1 and 2 are 273 and $119 \mathrm{Sm}^{2} \mathrm{~mol}^{-1}$ which indicates double salt (i.e. $\left[\mathrm{Co}(\text { phen })_{2} \mathrm{CO}_{3}\right]^{+}$, cfbz and $\left[\mathrm{Co}(\text { phen })_{2} \mathrm{CO}_{3}\right]^{+}, \mathrm{Cl}^{-}$) and single salt (i.e. $\left.\left[\mathrm{Co}(\mathrm{phen})_{2} \mathrm{CO}_{3}\right]^{+}, \mathbf{c n b z}\right)$ nature 
Table 1. Crystal data and refinement parameters of $\left[\mathrm{Co}(\text { phen })_{2} \mathrm{CO}_{3}\right]_{2}$ (2-chloro-5-fluorobenzoate). $\mathrm{Cl} \cdot 11 \mathrm{H}_{2} \mathrm{O}$ (1) and $\left[\mathrm{Co}(\text { phen })_{2} \mathrm{CO}_{3}\right]$ (2-chloro-5-nitrobenzoate) $\cdot 6 \mathrm{H}_{2} \mathrm{O}(2)$.

\begin{tabular}{|c|c|c|}
\hline & 1 & 2 \\
\hline Empirical formula & $\mathrm{C}_{57} \mathrm{H}_{57} \mathrm{Cl}_{2} \mathrm{Co}_{2} \mathrm{FN}_{8} \mathrm{O}_{19}$ & $\mathrm{C}_{32} \mathrm{H}_{31} \mathrm{ClCoN}_{5} \mathrm{O}_{13}$ \\
\hline$M_{\mathrm{w}}$ & $1365 \cdot 87$ & $788 \cdot 00$ \\
\hline Crystal system & Triclinic & Triclinic \\
\hline Space group & $\mathrm{P} \overline{1}$ & $\mathrm{P} \overline{1}$ \\
\hline$a /[\AA]$ & $7 \cdot 2801(15)$ & $10 \cdot 383(2)$ \\
\hline$b /[\AA]$ & $19 \cdot 585(4)$ & $12 \cdot 805(3)$ \\
\hline$c /[\AA]$ & $21 \cdot 295(4)$ & $13 \cdot 094(3)$ \\
\hline$\alpha /\left[^{\circ}\right]$ & $83 \cdot 07(3)$ & $82 \cdot 24(3)$ \\
\hline$\beta /\left[^{\circ}\right]$ & $86 \cdot 82(3)$ & $84 \cdot 31(3)$ \\
\hline$\gamma /\left[{ }^{\circ}\right]$ & $81 \cdot 24(3)$ & $77 \cdot 26(3)$ \\
\hline$V\left[\AA^{3}\right]$ & $2976 \cdot 9(10)$ & $1678 \cdot 2(6)$ \\
\hline$Z^{2}$ & 2 & 2 \\
\hline$D_{\mathrm{c}}\left[\mathrm{mg} \mathrm{m}^{-3}\right]$ & $1 \cdot 524$ & $1 \cdot 551$ \\
\hline$\mu /\left[\mathrm{mm}^{-1}\right]$ & 0.732 & 0.667 \\
\hline Reflections collected & 20400 & 21982 \\
\hline Unique reflections, $\left[R_{\text {int }}\right]$ & $8373[0 \cdot 0503]$ & $6517[0 \cdot 0329]$ \\
\hline \multicolumn{3}{|l|}{ Final $R$ indices } \\
\hline$R_{1}, w R_{2}[I>2 \sigma I]$ & $R 1=0 \cdot 0606, w R 2=0 \cdot 1622$ & $R 1=0.0520, w R 2=0.1476$ \\
\hline$R_{1}, w R_{2}$ (all data) & $R 1=0 \cdot 1063, w R 2=0 \cdot 1840$ & $R 1=0.0679, w R 2=0.1581$ \\
\hline
\end{tabular}

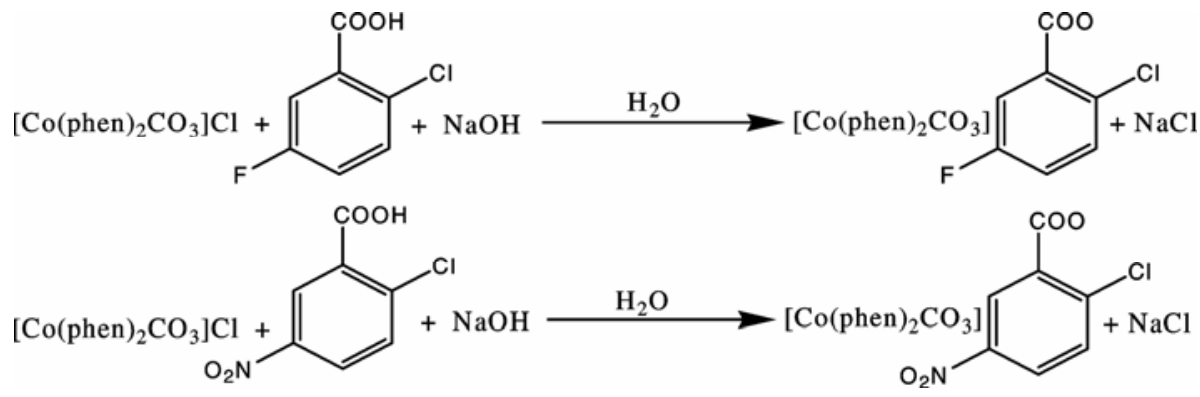

Scheme 1. Schematic representation of chemical reaction.

of 1 and 2 respectively. Thus conductance measurements revealed 1:1 electrolytic behaviour ${ }^{36}$ of the complex salts in aqueous media.

\subsection{Spectroscopic characterization}

FT-IR spectra of newly synthesized complex salts have been recorded in the region of $400-4000 \mathrm{~cm}^{-1}$. The IR spectral bands in the range 3363-3371, $3042-3088,1665-1673,1634-1602$ and $478-481 \mathrm{~cm}^{-1}$ were assigned to $v(\mathrm{O}-\mathrm{H})$ of $\mathrm{H}_{2} \mathrm{O}, v(=\mathrm{C}-\mathrm{H}), v(\mathrm{C}=\mathrm{O})$, $v(\mathrm{C}=\mathrm{C}) / v(\mathrm{C}=\mathrm{N})$ and $v(\mathrm{Co}-\mathrm{N})$, respectively in complex salts $\mathbf{1}$ and $\mathbf{2}$. These peaks are characteristic for the carbonato and 1,10-phenanthroline ligands attached to the cobalt(III) center.

In case of complex salt 1 , the bands at 1491, $1344,850,857$ and $747 \mathrm{~cm}^{-1}$ were assigned to
$v_{\mathrm{as}}(\mathrm{COO}), v_{\mathrm{s}}(\mathrm{COO}), v(\mathrm{C}-\mathrm{F}), \delta(\mathrm{C}=\mathrm{C})$ and $v(\mathrm{C}-\mathrm{Cl})$, respectively. These bands indicate the presence of ionic cfbz. Similar bands at 1650, 1490, 1320, 940 and $1638,1495,1284,746 \mathrm{~cm}^{-1}$ were observed in $\mathrm{Er}(\mathrm{Pfbz})_{3}{ }^{37}$ and $\left[\mathrm{Zn}(\mathrm{phen})_{2}(\mathrm{Pfbz})\left(\mathrm{H}_{2} \mathrm{O}\right)\right](\mathrm{Pfbz})\left(\mathrm{H}_{2} \mathrm{O}\right)_{2}{ }^{38}$ respectively which were assigned to $v(\mathrm{CO})$, $v_{\mathrm{as}}(\mathrm{COO}), v_{\mathrm{s}}(\mathrm{COO})$ and $v(\mathrm{C}-\mathrm{F})$ vibrations. In case of complex salt 2, the bands at 1602, 1426, 1515, 1341 and $744 \mathrm{~cm}^{-1}$ were assigned to $v_{\mathrm{as}}(\mathrm{COO})$, $v_{\mathrm{s}}(\mathrm{COO}), \quad v_{\mathrm{as}}\left(\mathrm{NO}_{2}\right), \quad v_{\mathrm{s}}\left(\mathrm{NO}_{2}\right)$ and $v(\mathrm{C}-\mathrm{Cl})$, respectively. These bands are in accordance with ionic cnbz. Similar bands have been reported for sodium salt and lanthanides(III) of 2-chloro-5-nitrobenzoate $^{39}$ at 1570-1610, 1380-1395, 1540, 1355-1350, $744-750 \mathrm{~cm}^{-1}$ and they were assigned to $v_{\mathrm{as}}(\mathrm{COO})$, $v_{\mathrm{s}}(\mathrm{COO}), v_{\mathrm{as}}\left(\mathrm{NO}_{2}\right), \quad v_{\mathrm{s}}\left(\mathrm{NO}_{2}\right)$ and $v(\mathrm{C}-\mathrm{Cl})$, respectively. The peak assignments have been made in consultation with literature values. ${ }^{40,41}$ 
The ${ }^{1} \mathrm{H}$ and ${ }^{19} \mathrm{~F}$ NMR spectra of the title complex salts were recorded in $\mathrm{D}_{2} \mathrm{O}$. In ${ }^{1} \mathrm{H}$ NMR spectrum of complex salt 1 , doublets at 9.21, 8.93, 8.50, 8.08 and $7.97 \mathrm{ppm}$ were assigned to protons $\mathrm{H} 9, \mathrm{H} 7, \mathrm{H} 2, \mathrm{H} 5$, $\mathrm{H} 6$ and multiplets at $8.30,7.43 \mathrm{ppm}$ were assigned to protons $\mathrm{H} 8, \mathrm{H} 3,4$ of the ligand 1,10-phenanthroline coordinated to $\mathrm{Co}$ (III). Other signals, two doublets and one singlet at 7.11,6.91 and $6.79 \mathrm{ppm}$ were assigned to $\mathrm{H} 3, \mathrm{H} 6$ and $\mathrm{H} 4$ protons of anion cfbz. Also in ${ }^{19} \mathrm{~F}$ NMR spectrum of complex salt, signal is observed at $-115.8 \mathrm{ppm}$ due to fluorine atom attached to $\mathrm{C} 5$ carbon atom of the anion $\mathbf{c f b z}$. Similar peak at $-113 \mathrm{ppm}$ has been reported for compound methyl $p$-fluorobenzoate. ${ }^{42}$

In ${ }^{1} \mathrm{H}$ NMR spectrum of complex salt 2 , doublets at $9.22,8.99,8.54,8.16$ and $8.08 \mathrm{ppm}$ were assigned to protons $\mathrm{H} 9, \mathrm{H} 7, \mathrm{H} 2, \mathrm{H} 5, \mathrm{H} 6$ and multiplets at $8.33,7.47 \mathrm{ppm}$ were assigned to protons $\mathrm{H} 8$ and $\mathrm{H} 3,4$ of the ligand 1,10-phenanthroline. Other signals at 7.93, 7.71 and 7.47 ppm were assigned to $\mathrm{H} 3$, $\mathrm{H} 6$ and $\mathrm{H} 4$ protons of anion cnbz. The signals observed in the NMR spectra are in good agreement with reported values in the literature. ${ }^{42,43}$

The electronic spectra of complex salts were recorded in water. For Co(III) complexes, two types of electronic transitions, i.e. ${ }^{1} \mathrm{~A}_{1 \mathrm{~g}} \rightarrow \mathrm{T}_{1 \mathrm{~g}}$ and ${ }^{1} \mathrm{~A}_{1 \mathrm{~g}} \rightarrow$ ${ }^{1} \mathrm{~T}_{2 \mathrm{~g}}$ are expected. In the $\left[\mathrm{Co}(\text { phen })_{2} \mathrm{CO}_{3}\right]^{+}$complexes, these transitions were observed around 500 and $360 \mathrm{~nm}$ as reported in the literature. ${ }^{44}$ In the title complex salts, these transitions were observed around 509 and $334 \mathrm{~nm}$. Characteristic peaks due to 1,10-phenanthroline groups coordinated to the Co(III) were observed at 269, 220 and 271, $220 \mathrm{~nm}$, respectively for $\mathbf{1}$ and $\mathbf{2}$ as in other related complex salts reported in the literature. ${ }^{45}$

\subsection{X-ray crystallography}

3.5a Coordination geometry and bonding: The complex salt $\left[\mathrm{Co}(\text { phen })_{2} \mathrm{CO}_{3}\right]_{2}$ (2-chloro-5-fluorobenzoate) $\mathrm{Cl}^{11} \mathrm{H}_{2} \mathrm{O}(1)$ crystallizes in triclinic crystal system (space group $\mathrm{P}_{\overline{1}}$ ). The asymmetric unit consists of two complex cations, $\left[\mathrm{Co}(\text { phen })_{2} \mathrm{CO}_{3}\right]^{+}$, one 2-chloro-5-fluorobenzoate, one chloride anion and eleven lattice water molecules. The ORTEP diagram of complex salt is shown in figure 1 .

In complex salt $\mathbf{1}$, the coordination around $\mathrm{Co}(1)$ is distorted octahedral in which the bite angle of carbonato group is deviated to the extent of $19.50^{\circ}$ (ideal value $=90^{\circ}$ ). The two 1,10 phenanthroline ligands coordinated to metal ion are almost orthogo- nal to the extent of $85.48^{\circ}$ (angle between the best least square planes). The pyridyl rings of each of the phenanthroline moieties attached to $\mathrm{Co}(1)$ are having average $\mathrm{N}-\mathrm{N}$ bite of $2.599 \AA$, whereas the $\mathrm{O}-\mathrm{O}$ bite distance of carbonato group is much lower to $2 \cdot 167 \AA$. As a consequence of the distorted octahedral coordination geometry, the phenanthroline moieties are not perfectly planar as evidenced from the torsional angles of $3.02^{\circ}(\mathrm{N} 1-\mathrm{C} 6-\mathrm{C} 7-\mathrm{N} 2)$ and $2.00^{\circ}$ (N3-C18-C19-N4). Another noteworthy feature is that the coordinated carbonato group is highly strained as angle $\mathrm{O}(2)-\mathrm{C}(1)-\mathrm{O}(3)$ is $110.27^{\circ}$ whereas the other two angles subtended around $\mathrm{C} 1$ are $123.04^{\circ}$ and $126.68^{\circ}$ respectively.

The coordination around other cation $(\mathrm{Co}(2))$ is hexacoordinated with a distorted octahedral environment in which the bite angle of carbonato group is deviated to the extent of $20.04^{\circ}$ (ideal value $=$ $90^{\circ}$ ) slightly higher than that of $\operatorname{Co}(1)$. On the other hand, the two 1,10 phenanthroline ligands coordinated to metal ion are deviated more from the orthogonality as they are making angle of $78.54^{\circ}$ with each other. In other related cobalt(III) phenanthroline complexes investigated, these aromatic rings are found almost orthogonal to each other. ${ }^{18-22}$ Probably, the structural constraints of the lattice necessitate such larger deviation. The pyridyl rings of each of the phenanthroline moieties are almost coplanar having torsional angles $-0 \cdot 30^{\circ}$ (N5-C31$\mathrm{C} 32-\mathrm{N} 6)$ and $0.55^{\circ}$ (N7-C43-C44-N8). As desired, the carboxylate group of the $\mathbf{c f b z}$ anion is almost perpendicular to the aromatic moiety (C56-C51C57-O8 torsion angle $=83.76^{\circ}$ ), which would minimize the resonance effect with the aromatic moiety.

The complex salt $\left[\mathrm{Co}\right.$ (phen) $\left.{ }_{2} \mathrm{CO}_{3}\right]$ (2-chloro-5-nitrobenzoate) $\cdot 6 \mathrm{H}_{2} \mathrm{O}$ (2) also crystallizes in triclinic crystal system (space group $\mathrm{P}_{\overline{1}}$ ). The asymmetric unit consists of one complex cation; $\left[\mathrm{Co}(\mathrm{phen})_{2} \mathrm{CO}_{3}\right]^{+}$, one 2-chloro-5-nitrobenzoate anion and six lattice water molecules (figure 2) out of which two water molecules are found disordered over two positions (due to this disorder any interaction involving these oxygen atoms (08 and 012) are not discussed further). The coordination around the metal centre as well as other features descried for complex 1 is also true for $\mathbf{2}$. Here the distorted octahedral coordination deviates by angle of $20.38^{\circ}$ (from the ideal value of $90^{\circ}$ ) as revealed from the geometrical parameters. The observed $\mathrm{N}-\mathrm{N}$ and $\mathrm{O}-\mathrm{O}$ bite distances are 2.61 and $2 \cdot 15 \AA$ and the orthogonality between two phenanthroline moieties is $79.97^{\circ}$. 


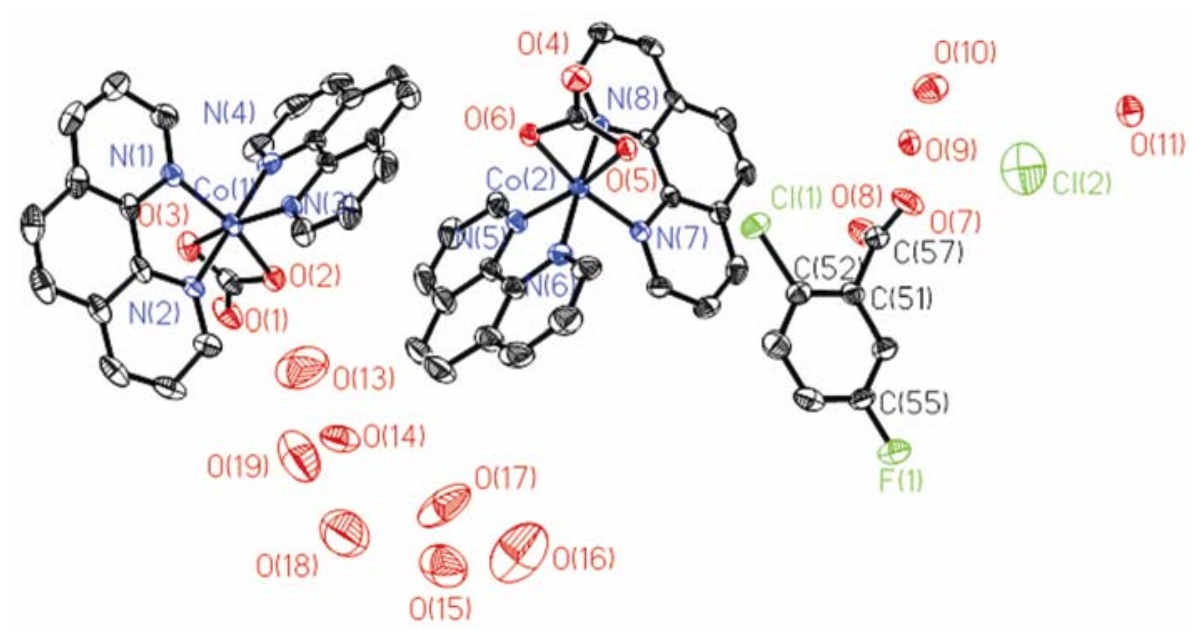

Figure 1. ORTEP diagram of complex salt 1.

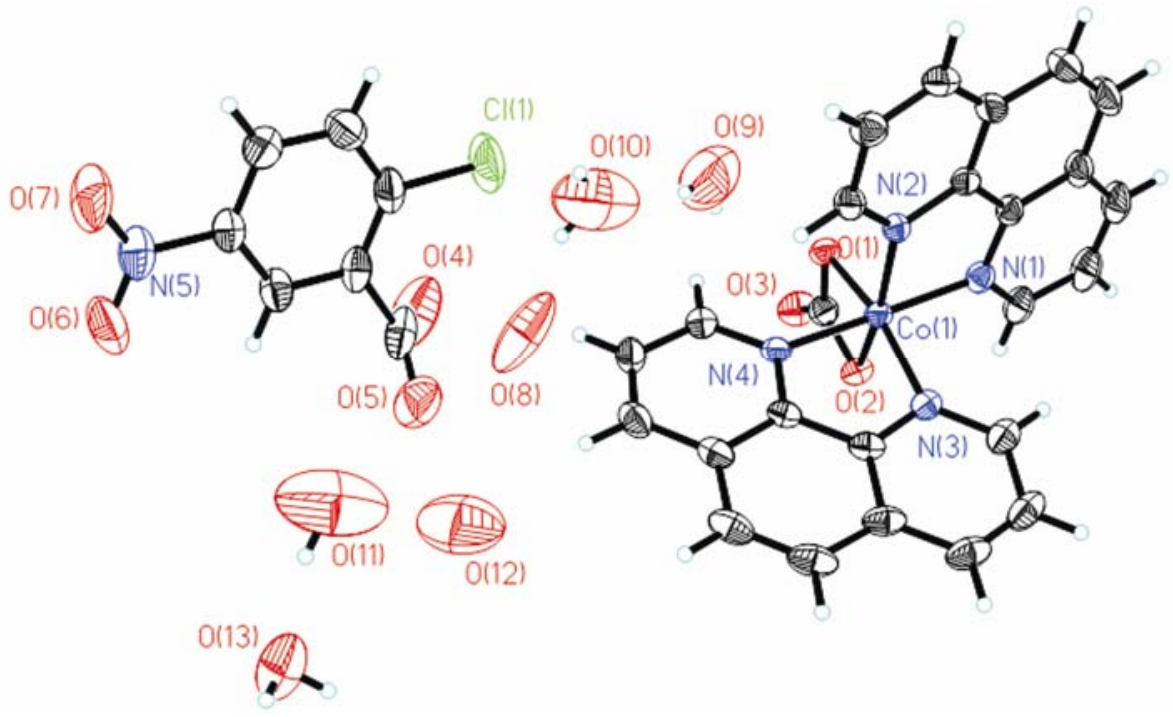

Figure 2. ORTEP diagram of complex salt 2.

The carboxylate group of the anion $\mathbf{c n b z}$ is also oriented out of plane from the aromatic ring (C27$\mathrm{C} 26-\mathrm{C} 32-\mathrm{O} 4$ torsion angle of $-60 \cdot 88^{\circ}$ ). But, it is much less than in $\mathbf{c f b z}\left(83.76^{\circ}\right)$ of complex salt 1 . Probably, the steric crowding coupled with second sphere interactions (vide intra) control the out of plane twist of respective carboxylate groups in $\mathbf{1}$ and 2. The $-\mathrm{NO}_{2}$ group is almost in the plane of the benzene ring (C29-C30-N5-O7 torsion angle is $\left.-0.51^{\circ}\right)$.

In both complex salts $\mathbf{1}$ and $\mathbf{2}$, the average $\mathrm{Co}-\mathrm{N}$, $\mathrm{Co}-\mathrm{O}$ bond lengths and bond angles $\mathrm{O}-\mathrm{Co}-\mathrm{O}$, cis$\mathrm{N}-\mathrm{Co}-\mathrm{N}$ and trans- $\mathrm{N}-\mathrm{Co}-\mathrm{N}$ are quite similar to those reported in related complexes. ${ }^{18-22}$ As expected, the bond lengths and bond angles for anion, i.e. cnbz in complex salts $\mathbf{2}$ are similar to those ionic complexes of cnbz reported in the literature ${ }^{46-49}$ It is to be noted that no complex salt containing $\mathbf{c f b z}$ is reported till now. Selected bond lengths and bond angles of the complex salt $\mathbf{1}$ and $\mathbf{2}$ are given in tables 2 and 3 .

3.5b Packing: The packing analysis of complex salt 1 reveals that crystal lattice is stabilized by a combination of strong and weak hydrogen bonding interactions of type the $\mathrm{O}-\mathrm{H} \cdots \mathrm{O}$ (water), $\mathrm{O}-\mathrm{H} \cdots \mathrm{O}$ (carbonato), $\mathrm{O}-\mathrm{H} \cdots \mathrm{O}$ (benzoate), $\mathrm{C}-\mathrm{H} \cdots \mathrm{O}$ (water), $\mathrm{C}-\mathrm{H} \cdots \mathrm{O}$ (carbonato), $\mathrm{C}-\mathrm{H} \cdots \mathrm{Cl}$ (free), $\mathrm{C}-\mathrm{H} \cdots \mathrm{Cl}$ (benzoate) and $\mathrm{C}-\mathrm{H} \cdots \mathrm{F}$ along with $\pi-\pi$ stacking interactions. The hydrogen bonding parameters are given in table 4 . It is clear from these hydrogen bonding interactions that hydrogen bonding 
Table 2. Selected bond lengths and bond angles $\left(\AA,^{\circ}\right)$ for complex salt $\left[\mathrm{Co}(\mathrm{phen})_{2} \mathrm{CO}_{3}\right]_{2}$ (2-chloro-5-fluorobenzoate). $\mathrm{Cl} \cdot 11 \mathrm{H}_{2} \mathrm{O}$ (1).

\begin{tabular}{|c|c|c|c|}
\hline \multicolumn{4}{|l|}{ Cation 1} \\
\hline $\mathrm{Co}(1)-\mathrm{N}(1)$ & $1.958(4)$ & $\mathrm{Co}(1)-\mathrm{O}(2)$ & $1.890(4)$ \\
\hline $\mathrm{Co}(1)-\mathrm{N}(2)$ & $1.940(4)$ & $\mathrm{Co}(1)-\mathrm{O}(3)$ & $1 \cdot 884(4)$ \\
\hline $\mathrm{Co}(1)-\mathrm{N}(3)$ & $1.953(4)$ & $\mathrm{Co}(1)-\mathrm{N}(4)$ & $1.947(4)$ \\
\hline $\mathrm{O}(3)-\mathrm{Co}(1)-\mathrm{O}(2)$ & $70 \cdot 10(18)$ & $\mathrm{O}(3)-\mathrm{Co}(1)-\mathrm{N}(3)$ & $169.00(18)$ \\
\hline $\mathrm{N}(1)-\mathrm{Co}(1)-\mathrm{N}(2)$ & $83.63(19)$ & $\mathrm{O}(2)-\mathrm{Co}(1)-\mathrm{N}(3)$ & $99.66(17)$ \\
\hline $\mathrm{N}(1)-\mathrm{Co}(1)-\mathrm{N}(3)$ & $92 \cdot 04(17)$ & $\mathrm{N}(2)-\mathrm{Co}(1)-\mathrm{N}(3)$ & $96 \cdot 18(17)$ \\
\hline $\mathrm{N}(1)-\mathrm{Co}(1)-\mathrm{N}(4)$ & $95.86(18)$ & $\mathrm{N}(4)-\mathrm{Co}(1)-\mathrm{N}(3)$ & $83 \cdot 6(2)$ \\
\hline $\mathrm{N}(1)-\mathrm{Co}(1)-\mathrm{O}(2)$ & $167 \cdot 61(17)$ & $\mathrm{O}(3)-\mathrm{Co}(1)-\mathrm{N}(4)$ & $92 \cdot 08(19)$ \\
\hline $\mathrm{N}(1)-\mathrm{Co}(1)-\mathrm{O}(3)$ & $98 \cdot 47(19)$ & $\mathrm{O}(2)-\mathrm{Co}(1)-\mathrm{N}(4)$ & $89.50(17)$ \\
\hline $\mathrm{O}(2)-\mathrm{Co}(1)-\mathrm{N}(2)$ & $91 \cdot 05(17)$ & $\mathrm{N}(2)-\mathrm{Co}(1)-\mathrm{N}(4)$ & $179 \cdot 44(19)$ \\
\hline $\mathrm{O}(3)-\mathrm{Co}(1)-\mathrm{N}(2)$ & $88 \cdot 22(16)$ & & \\
\hline \multicolumn{4}{|l|}{ Cation 2} \\
\hline $\mathrm{Co}(2)-\mathrm{N}(5)$ & $1.946(4)$ & $\mathrm{Co}(2)-\mathrm{O}(5)$ & $1 \cdot 886(3)$ \\
\hline $\mathrm{Co}(2)-\mathrm{N}(6)$ & $1.946(4)$ & $\mathrm{Co}(2)-\mathrm{O}(6)$ & $1.897(3)$ \\
\hline $\mathrm{Co}(2)-\mathrm{N}(7)$ & $1.950(4)$ & $\mathrm{Co}(2)-\mathrm{N}(8)$ & $1.948(4)$ \\
\hline $\mathrm{O}(5)-\mathrm{Co}(2)-\mathrm{O}(6)$ & $69.57(15)$ & $\mathrm{N}(6)-\mathrm{Co}(2)-\mathrm{N}(7)$ & $93.92(17)$ \\
\hline $\mathrm{O}(5)-\mathrm{Co}(2)-\mathrm{N}(5)$ & $166 \cdot 44(16)$ & $\mathrm{O}(5)-\mathrm{Co}(2)-\mathrm{N}(7)$ & $99 \cdot 54(16)$ \\
\hline $\mathrm{O}(6)-\mathrm{Co}(2)-\mathrm{N}(5)$ & $97 \cdot 61(16)$ & $\mathrm{N}(8)-\mathrm{Co}(2)-\mathrm{N}(7)$ & $84 \cdot 06(17)$ \\
\hline $\mathrm{O}(5)-\mathrm{Co}(2)-\mathrm{N}(6)$ & $90.95(17)$ & $\mathrm{N}(6)-\mathrm{Co}(2)-\mathrm{N}(8)$ & $177 \cdot 72(18)$ \\
\hline $\mathrm{O}(6)-\mathrm{Co}(2)-\mathrm{N}(6)$ & $89 \cdot 84(16)$ & $\mathrm{O}(5)-\mathrm{Co}(2)-\mathrm{N}(8)$ & $88 \cdot 36(15)$ \\
\hline $\mathrm{N}(5)-\mathrm{Co}(2)-\mathrm{N}(6)$ & $84 \cdot 42(19)$ & $\mathrm{O}(6)-\mathrm{Co}(2)-\mathrm{N}(8)$ & $91.96(15)$ \\
\hline $\mathrm{O}(6)-\mathrm{Co}(2)-\mathrm{N}(7)$ & $168 \cdot 56(15)$ & $\mathrm{N}(5)-\mathrm{Co}(2)-\mathrm{N}(8)$ & $96 \cdot 73(17)$ \\
\hline $\mathrm{N}(5)-\mathrm{Co}(2)-\mathrm{N}(7)$ & $93 \cdot 51(17)$ & & \\
\hline \multicolumn{4}{|l|}{ Anion } \\
\hline$C(51)-C(57)$ & $1.537(7)$ & $\mathrm{O}(7)-\mathrm{C}(57)$ & $1 \cdot 240(6)$ \\
\hline $\mathrm{Cl}(1)-\mathrm{C}(52)$ & $1.762(5)$ & $\mathrm{O}(8)-\mathrm{C}(57)$ & $1.239(6)$ \\
\hline $\mathrm{F}(1)-\mathrm{C}(55)$ & $1 \cdot 366(6)$ & & \\
\hline $\mathrm{O}(7)-\mathrm{C}(57)-\mathrm{O}(8)$ & $126 \cdot 2(6)$ & $\mathrm{O}(7)-\mathrm{C}(57)-\mathrm{C}(51)$ & $116 \cdot 8(5)$ \\
\hline $\mathrm{O}(8)-\mathrm{C}(57)-\mathrm{C}(51)$ & $117 \cdot 0(5)$ & & \\
\hline
\end{tabular}

Table 3. Selected bond lengths and bond angles $\left(\AA,{ }^{\circ}\right)$ for complex salt $\left[\mathrm{Co}(\mathrm{phen})_{2} \mathrm{CO}_{3}\right]$ (2-chloro-5-nitrobenzoate) $6 \mathrm{H}_{2} \mathrm{O}(2)$.

\begin{tabular}{llll}
\hline Cation & & & \\
$\mathrm{Co}(1)-\mathrm{O}(1)$ & $1 \cdot 890(2)$ & $\mathrm{Co}(1)-\mathrm{N}(4)$ & $1 \cdot 934(2)$ \\
$\mathrm{Co}(1)-\mathrm{O}(2)$ & $1 \cdot 895(2)$ & $\mathrm{O}(1)-\mathrm{C}(25)$ & $1 \cdot 312(3)$ \\
$\mathrm{Co}(1)-\mathrm{N}(1)$ & $1 \cdot 937(2)$ & $\mathrm{O}(2)-\mathrm{C}(25)$ & $1 \cdot 322(3)$ \\
$\mathrm{Co}(1)-\mathrm{N}(3)$ & $1 \cdot 964(2)$ & $\mathrm{O}(3)-\mathrm{C}(25)$ & $1 \cdot 219(4)$ \\
$\mathrm{Co}(1)-\mathrm{N}(2)$ & $1 \cdot 964(2)$ & $\mathrm{N}(4)-\mathrm{Co}(1)-\mathrm{N}(3)$ & $83 \cdot 97(10)$ \\
$\mathrm{O}(2)-\mathrm{Co}(1)-\mathrm{O}(1)$ & $69 \cdot 23(9)$ & $\mathrm{N}(1)-\mathrm{Co}(1)-\mathrm{N}(3)$ & $95 \cdot 11(10)$ \\
$\mathrm{O}(1)-\mathrm{Co}(1)-\mathrm{N}(4)$ & $91 \cdot 69(9)$ & $\mathrm{O}(1)-\mathrm{Co}(1)-\mathrm{N}(2)$ & $97 \cdot 60(9)$ \\
$\mathrm{O}(2)-\mathrm{Co}(1)-\mathrm{N}(4)$ & $91 \cdot 05(9)$ & $\mathrm{O}(2)-\mathrm{Co}(1)-\mathrm{N}(2)$ & $166 \cdot 34(9)$ \\
$\mathrm{O}(1)-\mathrm{Co}(1)-\mathrm{N}(1)$ & $89 \cdot 97(9)$ & $\mathrm{N}(4)-\mathrm{Co}(1)-\mathrm{N}(2)$ & $93 \cdot 04(9)$ \\
$\mathrm{O}(2)-\mathrm{Co}(1)-\mathrm{N}(1)$ & $92 \cdot 38(10)$ & $\mathrm{N}(1)-\mathrm{Co}(1)-\mathrm{N}(2)$ & $83 \cdot 73(10)$ \\
$\mathrm{N}(4)-\mathrm{Co}(1)-\mathrm{N}(1)$ & $176 \cdot 53(9)$ & $\mathrm{N}(3)-\mathrm{Co}(1)-\mathrm{N}(2)$ & $69 \cdot 00(10)$ \\
$\mathrm{O}(1)-\mathrm{Co}(1)-\mathrm{N}(3)$ & $165 \cdot 92(9)$ & & \\
$\mathrm{O}(2)-\mathrm{Co}(1)-\mathrm{N}(3)$ & $97 \cdot 39(9)$ & & \\
& & & \\
$\mathrm{Anin}$ & & & $122 \cdot 9(4)$ \\
$\mathrm{N}(5)-\mathrm{O}(7)$ & $1 \cdot 204(5)$ & $\mathrm{O}(7)-\mathrm{N}(5)-\mathrm{O}(6)$ & $118 \cdot 9(4)$ \\
$\mathrm{N}(5)-\mathrm{O}(6)$ & $1 \cdot 220(5)$ & $\mathrm{O}(7)-\mathrm{N}(5)-\mathrm{C}(30)$ & $118 \cdot 2(4)$ \\
$\mathrm{N}(5)-\mathrm{C}(30)$ & $1 \cdot 462(4)$ & $\mathrm{O}(6)-\mathrm{N}(5)-\mathrm{C}(30)$ & $126 \cdot 8(5)$ \\
$\mathrm{O}(4)-\mathrm{C}(32)$ & $1 \cdot 201(6)$ & $\mathrm{O}(4)-\mathrm{C}(32)-\mathrm{O}(5)$ & $117 \cdot 5(5)$ \\
$\mathrm{O}(5)-\mathrm{C}(32)$ & $1 \cdot 251(6)$ & $\mathrm{O}(4)-\mathrm{C}(32)-\mathrm{C}(26)$ & $115 \cdot 7(4)$ \\
$\mathrm{C}(26)-\mathrm{C}(32)$ & $1 \cdot 518(6)$ & $\mathrm{O}(5)-\mathrm{C}(32)-\mathrm{C}(26)$ & \\
\hline & & &
\end{tabular}


Table 4. Hydrogen bonding parameters $\left(\AA,{ }^{\circ}\right)$ for complex salt $\left[\mathrm{Co}(\mathrm{phen})_{2} \mathrm{CO}_{3}\right]_{2}$ (2-chloro-5-Fluorobenzoate). $\mathrm{Cl} .11 \mathrm{H}_{2} \mathrm{O}(\mathbf{1})$.

\begin{tabular}{|c|c|c|c|}
\hline $\mathrm{D}-\mathrm{H} \cdots \mathrm{A}$ & $\mathrm{D} \cdots \mathrm{A}$ & $\mathrm{H} \cdots \mathrm{A}$ & Angle D-H-A \\
\hline O9-H9B...Cl2 & $2 \cdot 723(5)$ & $1 \cdot 889(4)$ & $166 \cdot 1(3)$ \\
\hline O9-H9C...O8 & $2 \cdot 747(6)$ & $1 \cdot 889(4)$ & $164 \cdot 9(3)$ \\
\hline O10-H10B...O7 & $2 \cdot 778(6)$ & $1.991(4)$ & $158 \cdot 2(3)$ \\
\hline $\mathrm{O} 10-\mathrm{H} 10 \mathrm{C} \ldots \mathrm{O} 4^{\mathrm{i}}$ & $2 \cdot 873(6)$ & $2 \cdot 083(4)$ & $152 \cdot 3(3)$ \\
\hline O11-H11B...O12 & $2 \cdot 801(5)$ & $1 \cdot 934(4)$ & $164 \cdot 1(3)$ \\
\hline $\mathrm{O} 11-\mathrm{H} 11 \mathrm{C} \ldots \mathrm{Cl} 2$ & $2 \cdot 785(6)$ & $1.942(4)$ & $160 \cdot 0(3)$ \\
\hline $\mathrm{O} 12-\mathrm{H} 12 \mathrm{~B} \ldots \mathrm{Cl} 2^{\mathrm{ii}}$ & $2 \cdot 894(6)$ & $2 \cdot 197(4)$ & $139 \cdot 5(3)$ \\
\hline $\mathrm{O} 12-\mathrm{H} 12 \mathrm{C} \ldots \mathrm{O} 7^{\mathrm{ii}}$ & $2 \cdot 839(7)$ & $2 \cdot 013(5)$ & $161 \cdot 8(3)$ \\
\hline $\mathrm{O} 13-\mathrm{H} 13 \mathrm{~B} \ldots \mathrm{O} 1^{\mathrm{iii}}$ & $2.731(10)$ & $1.952(5)$ & $154 \cdot 5(6)$ \\
\hline O13-H13C...O19 & $2.759(12)$ & $1.910(8)$ & $179 \cdot 2(6)$ \\
\hline O14-H14C...O19 & $3 \cdot 073(10)$ & $2 \cdot 266(8)$ & $174 \cdot 7(4)$ \\
\hline O15-H15B...O17 & $3 \cdot 011(12)$ & $2 \cdot 223(10)$ & $152 \cdot 5(6)$ \\
\hline O16-H16B...O15 & $2 \cdot 709(12)$ & $1 \cdot 915(8)$ & $154 \cdot 8(7)$ \\
\hline $\mathrm{O} 16-\mathrm{H} 16 \mathrm{C} \ldots \mathrm{O} 17^{\mathrm{v}}$ & $3 \cdot 136(13)$ & $2 \cdot 564(8)$ & $123 \cdot 5(7)$ \\
\hline O17-H17B...O14 & $2 \cdot 863(9)$ & $2 \cdot 115(6)$ & $152 \cdot 2(6)$ \\
\hline O18-H18C...O19 & $2 \cdot 510(11)$ & $1 \cdot 654(8)$ & $173 \cdot 6(7)$ \\
\hline $\mathrm{C} 2-\mathrm{H} 2 \mathrm{~A} \ldots \mathrm{O} 12^{\mathrm{vi}}$ & $3 \cdot 388(8)$ & $2 \cdot 603(4)$ & $142 \cdot 5(4)$ \\
\hline $\mathrm{C} 2-\mathrm{H} 2 \mathrm{~A} \ldots \mathrm{O} 11^{\mathrm{vi}}$ & $3 \cdot 302(8)$ & $2 \cdot 648(4)$ & $128 \cdot 0(4)$ \\
\hline $\mathrm{C} 4-\mathrm{H} 4 \mathrm{~A} \ldots \mathrm{O} 8^{\mathrm{vii}}$ & $3 \cdot 328(8)$ & $2 \cdot 586(4)$ & $137 \cdot 1(4)$ \\
\hline C11-H11A...O1 & $3 \cdot 462(9)$ & $2 \cdot 539(5)$ & $171 \cdot 9(4)$ \\
\hline $\mathrm{C} 12-\mathrm{H} 12 \mathrm{~A} \ldots \mathrm{F} 1^{\mathrm{v}}$ & $3 \cdot 326(7)$ & $2 \cdot 423(3)$ & $163 \cdot 7(4)$ \\
\hline C14-H14A...O1 ${ }^{\text {iii }}$ & $3 \cdot 102(8)$ & $2 \cdot 343(5)$ & $138 \cdot 5(4)$ \\
\hline C16-H16A...O6 & $3 \cdot 274(8)$ & $2 \cdot 487(3)$ & $142 \cdot 5(4)$ \\
\hline $\mathrm{C} 22-\mathrm{H} 22 \mathrm{~A} \ldots \mathrm{O} 9^{\mathrm{vi}}$ & $3 \cdot 332(9)$ & $2 \cdot 602(4)$ & $135 \cdot 7(5)$ \\
\hline $\mathrm{C} 24-\mathrm{H} 24 \mathrm{~A} \ldots \mathrm{O} 11^{\mathrm{ix}}$ & $3 \cdot 475(9)$ & $2 \cdot 550(4)$ & $172 \cdot 9(6)$ \\
\hline $\mathrm{C} 27-\mathrm{H} 27 \mathrm{~A} \ldots \mathrm{O} 4^{\mathrm{iv}}$ & $3 \cdot 216(7)$ & $2 \cdot 349(4)$ & $155 \cdot 0(4)$ \\
\hline C35-H35A...O14 & $3 \cdot 508(10)$ & $2 \cdot 630(5)$ & $157 \cdot 6(5)$ \\
\hline C $37-H 37 \mathrm{~A} \ldots \mathrm{O} 16^{\mathrm{x}}$ & $3 \cdot 376(12)$ & $2 \cdot 647(10)$ & $135 \cdot 8(5)$ \\
\hline С $39-H 39 A \ldots O 15^{v}$ & $3 \cdot 369(9)$ & $2 \cdot 544(7)$ & $148 \cdot 1(4)$ \\
\hline C40-H40A...O18 & $3 \cdot 402(10)$ & $2 \cdot 505(8)$ & $162 \cdot 2(4)$ \\
\hline C46-H46A...O $4^{\mathrm{vi}}$ & $3 \cdot 466(7)$ & $2 \cdot 548(4)$ & $169 \cdot 2(4)$ \\
\hline $\mathrm{C} 48-\mathrm{H} 48 \mathrm{~A} \ldots \mathrm{O} 5^{\mathrm{vi}}$ & $3 \cdot 479(7)$ & $2 \cdot 709(4)$ & $140 \cdot 7(3)$ \\
\hline $\mathrm{C} 48-\mathrm{H} 48 \mathrm{~A} \ldots \mathrm{Cl1}{ }^{\mathrm{vi}}$ & $3 \cdot 648(5)$ & $2 \cdot 907(2)$ & $137 \cdot 7(3)$ \\
\hline C50-H50A...O9 $9^{\mathrm{vi}}$ & $3 \cdot 297(6)$ & $2 \cdot 534(4)$ & $139 \cdot 5(3)$ \\
\hline $\mathrm{C} 54-\mathrm{H} 54 \mathrm{~A} \ldots \mathrm{O} 14^{\mathrm{v}}$ & $3.735(8)$ & $2 \cdot 810(5)$ & $172 \cdot 7(4)$ \\
\hline
\end{tabular}

$D=$ donor, $\mathrm{A}=$ acceptor. Equivalent positions: (i) $-x+1,-y+1,-z+1$, (ii) $-x+1,-y$, $-z+1$, (iii) $x+1,+y,+z$, (iv) $x-1,+y,+z$, (v) $-\mathrm{x},-y+1,-z+2$, (vi) $-\mathrm{x},-y+1,-z+1$, (vii) $x,+y+1,+z$, (viii) $-\mathrm{x}-1,-y+2,-z+2$, (ix) $-x-1,-y+1,-z+1$, (x) $-x+1,-y+1,-z+2$



Figure 3. First set of clustered water molecules with their graph set patterns. Dotted lines represent hydrogen bonds. capabilities of all groups that can act as hydrogen bond acceptor are utilized fully towards lattice stabilization. The two carboxylate oxygen atoms 07 and $\mathrm{O} 8$ are involved in bifurcated hydrogen bonds of type $\mathrm{O}-\mathrm{H} \ldots \mathrm{O}$ and $\mathrm{C}-\mathrm{H} \ldots \mathrm{O}(\mathrm{O} 10-\mathrm{H} 10 \mathrm{~B} \ldots$ $\mathrm{O} 7=1.991, \quad \mathrm{O} 12-\mathrm{H} 12 \mathrm{C} \ldots \mathrm{O} 7=2.013, \quad \mathrm{O} 9-\mathrm{H} 9 \mathrm{C} \ldots$ $\mathrm{O} 8=1.889$ and $\mathrm{C} 4-\mathrm{H} 4 \mathrm{~A} \ldots \mathrm{O} 8=2.586 \AA$ ). The oxygen atoms of the carbonato groups are also involved in hydrogen bonding as they are forming one $\mathrm{O}$ $\mathrm{H}$... O and two $\mathrm{C}-\mathrm{H}$... O hydrogen bonds (table 4).

It is noteworthy that the lattice water molecules are clustered into two sets. In the first set, water molecules $09,010,011,012$ and two oxygen atoms of $\mathbf{c f b z}(\mathrm{O} 7$ and $\mathrm{O} 8)$ and the free chloride 


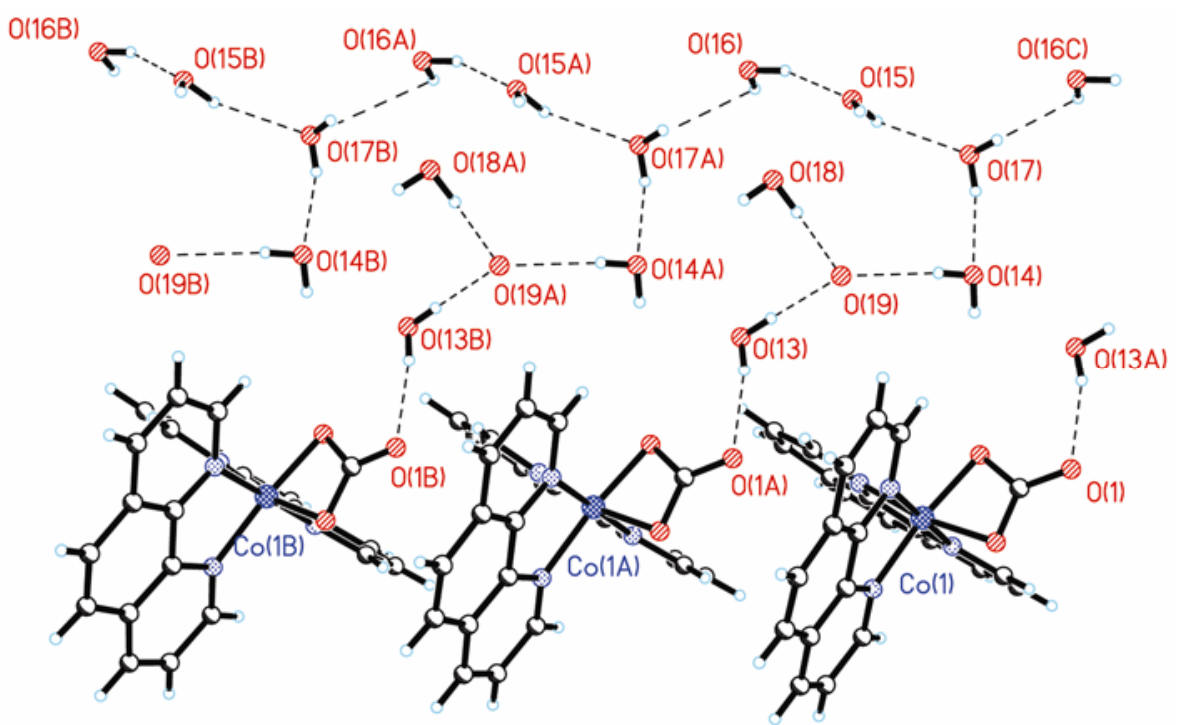

Figure 4. Second set of clustered water molecules. First (figure 3 ) and second set of cluster are not directly linked, but through charged species in the lattice.



Figure 5. Packing of $\mathbf{1}$ viewed down 'a' axis. Note the orientation of $\left[\mathrm{Co}(\mathrm{phen})_{2} \mathrm{CO}_{3}\right]^{+}$cation along the diagonal of the $b c$ place of the unit cell (marked as an arrow). Hydrogen bonds are marked as dotted lines.

ions are involved. This organization resulted in the formation of two graph set hydrogen bonding patterns. ${ }^{50-52}$ of type $\mathbf{R}^{\mathbf{4}}{ }_{\mathbf{3}} \mathbf{( 1 0 )}$ and $\mathbf{R}_{\mathbf{4}}^{\mathbf{6}} \mathbf{( 1 2 )}$ (figure 3 ). In $\mathbf{R}^{4}{ }_{3}(\mathbf{1 0})$, hydrogen atoms of $\mathrm{O} 9$ and $\mathrm{O} 12$ are acting as donor atoms and $\mathrm{Cl}(2), \mathrm{O} 7$ and $\mathrm{O} 8$ are acting as acceptors while in $\mathbf{R}^{6}{ }_{4}(\mathbf{1 2}), \mathrm{O} 11, \mathrm{O} 12$ and $\mathrm{Cl}(2)$ are involved. In the second cluster, seven lattice water molecules (O13, O14, O15, O16, 017, 018 and 019) are involved in hydrogen bonding interactions which are further joined to oxygen atom of the carbonato groups (figure 4). Interestingly, these two clustered set of water molecules are themselves not linked though any $\mathrm{O}-\mathrm{H}$... O type hydrogen bonds. That is, they are located separately in two different pockets of the lattice and are only linked to the ionic species in the lattice. The complex cations are arranged in zig-zag layers (shown as stick model in figure 5). Both the phenanthroline moieties attached to cobalt(III) are involved in the $\pi-\pi$ stacking interactions from both sides, the nearest approach being $3.564 \AA$ (one side) and $3.461 \AA$ (from the other side). In between the layers, anions $\mathbf{c f b z}, \mathrm{Cl}^{-}$and lattice water molecules reside (shown as space-filling model in figure 5). Overall, the unison of large number of non-covalent interactions of type $\mathrm{O}-\mathrm{H} \ldots \mathrm{O}$ (water), $\mathrm{C}-\mathrm{H} \ldots \mathrm{O}$ (benzoate), $\mathrm{C}-\mathrm{H} \cdots \mathrm{O}$ (water), $\mathrm{C}-\mathrm{H} \cdots \mathrm{O}$ (carbonato), $\mathrm{C}-\mathrm{H} \cdots \mathrm{F}, \mathrm{C}-\mathrm{H} \cdots \mathrm{Cl}$, is stabilizing the crystal lattice and provide the driving force for the formation of complex of the composition $\left[\mathrm{Co}(\text { phen })_{2} \mathrm{CO}_{3}\right]_{2}$ (2-chloro-5-fluorobenzoate) $\mathrm{Cl} .11 \mathrm{H}_{2} \mathrm{O}$ in addition to the electrostatic forces of attraction.

The crystal lattice of the complex salt $\mathbf{2}$ is also stabilized by the interplay of large number of non-covalent interactions like $\mathrm{O}-\mathrm{H} \cdots \mathrm{O}, \mathrm{C}-\mathrm{H} \cdots \mathrm{O}$ (water), $\mathrm{C}-\mathrm{H} \cdots \mathrm{O}$ (nitro), $\mathrm{C}-\mathrm{H} \cdots \mathrm{O}$ (carbonato), $\mathrm{C}-\mathrm{H} \cdots \mathrm{Cl}$ type hydrogen bonding interactions (table 5) 
Table 5. Hydrogen bonding parameters $\left(\AA,{ }^{\circ}\right)$ for complex salt $\left[\mathrm{Co}(\text { phen })_{2} \mathrm{CO}_{3}\right]$ (2-chloro-5-nitrobenzoate) $\cdot 6 \mathrm{H}_{2} \mathrm{O}(2)$.

\begin{tabular}{|c|c|c|c|}
\hline $\mathrm{D}-\mathrm{H} \cdots \mathrm{A}$ & $\mathrm{D} \cdots \mathrm{A}$ & $\mathrm{H} \cdots \mathrm{A}$ & Angle D-H-A \\
\hline O9-H9B...O10 & $2 \cdot 955(10)$ & $2 \cdot 122(9)$ & $160 \cdot 2(6)$ \\
\hline O11-H11B...O5 & $2 \cdot 855(9)$ & $2 \cdot 314(5)$ & $119 \cdot 7(5)$ \\
\hline O11-H11C...O13 & $2 \cdot 757(8)$ & $1 \cdot 894(4)$ & $159 \cdot 5(5)$ \\
\hline O10-H10C...Cl1 & $3 \cdot 701(9)$ & $2 \cdot 968(2)$ & $149 \cdot 2(6)$ \\
\hline $\mathrm{C} 2-\mathrm{H} 2 \mathrm{~A} \ldots \mathrm{O} 13^{\mathrm{i}}$ & $3 \cdot 514(7)$ & $2 \cdot 631(5)$ & $158 \cdot 6(3)$ \\
\hline C9-H9A... Cl1 & $3 \cdot 766(9)$ & $2 \cdot 837(2)$ & $178 \cdot 5(3)$ \\
\hline C11-H11A...O6 ${ }^{\mathrm{ii}}$ & $3 \cdot 473(6)$ & $2 \cdot 657(5)$ & $146 \cdot 9(2)$ \\
\hline $\mathrm{C} 12-\mathrm{H} 12 \mathrm{~A} \ldots \mathrm{O} 7^{\mathrm{ii}}$ & $3 \cdot 240(6)$ & $2 \cdot 421(5)$ & $147 \cdot 0(2)$ \\
\hline C13-H13A...O $4^{\text {iii }}$ & $3 \cdot 531(6)$ & $2 \cdot 741(5)$ & $143 \cdot 4(2)$ \\
\hline C15-H15A...O13 & $3 \cdot 455(5)$ & $2 \cdot 659(4)$ & $144 \cdot 0(2)$ \\
\hline $\mathrm{C} 20-\mathrm{H} 20 \mathrm{~A} \ldots \mathrm{O} 3^{\mathrm{iv}}$ & $3 \cdot 347(5)$ & $2 \cdot 496(2)$ & $152 \cdot 3(2)$ \\
\hline $\mathrm{C} 22-\mathrm{H} 22 \mathrm{~A} \ldots \mathrm{O} 9^{\mathrm{iv}}$ & $3 \cdot 561(9)$ & $2 \cdot 761(8)$ & $144 \cdot 7(3)$ \\
\hline C23-H23 A...O4 & $3 \cdot 726(6)$ & $2 \cdot 820(5)$ & $165 \cdot 1(2)$ \\
\hline C24-H24A...O10 & $3 \cdot 349(8)$ & $2 \cdot 560(7)$ & $142 \cdot 8(3)$ \\
\hline $\mathrm{C} 28-\mathrm{H} 28 \mathrm{~A} \ldots \mathrm{O} 11^{\mathrm{ii}}$ & $3 \cdot 499(8)$ & $2 \cdot 609(7)$ & $160 \cdot 4(3)$ \\
\hline
\end{tabular}

$\mathrm{D}=$ donor, $\mathrm{A}=$ acceptor. Equivalent positions: (i) $x+1,+y+1,+\mathrm{z}$, (ii) $-x+1$, $y+2,-z$, (iii) $x,+y+1,+z$, (iv) $x-1,+y,+z$

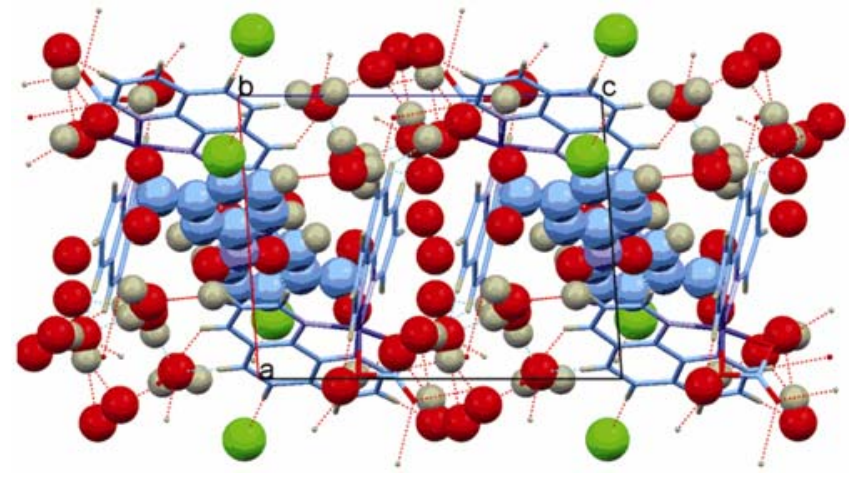

Figure 6. Packing of 2 showing the box-like voids of phenanthroline moiety generated through $\overline{1}$. The anions and lattice water molecules reside in these voids and extensively hydrogen bonded (dotted line).

and $\pi-\pi$ stacking interactions. A detailed perusal of table 5 shows that all the hydrogen bond acceptor groups $\left(-\mathrm{NO}_{2},-\mathrm{COO},-\mathrm{Cl}\right.$ and $\left.>\mathrm{C}=\mathrm{O}\right)$ are oriented in such a way that their hydrogen bonding capabilities are fully utilized. The two oxygen atoms of nitro group are involved in hydrogen bonding with $\mathrm{C}-\mathrm{H}$ groups of 1,10-phenanthroline moiety (C11H11A...O6 = 2.657 $\AA, \quad \mathrm{C} 12-\mathrm{H} 12 \mathrm{~A} \ldots \mathrm{O} 7=2.421 \AA$ ). The phenanthroline moieties coordinated to the cobalt(III) center are wide apart in spatial disposition (angle between the least square planes $=79.97^{\circ}$ ) and this arrangement, when placed centrosymmetrically, box-like voids are created (figure 6). Due to $\overline{1}$ symmetry, anions are arranged in such a way that the $-\mathrm{COO}^{-}$and $-\mathrm{NO}_{2}$ moieties of neighbouring molecules are placed just opposite to each other and are extensively hydrogen bonded. The box-like arrangement of the cations infinitely repeats with a number of $\mathrm{C}-\mathrm{H}$... O hydrogen bonds to complete the packing in third dimension. The anionic moieties placed in the box-like arrangement are also involved in $\pi-\pi$ interactions $(3.720 \AA$, distance between the centeriods of two anionic moieties).

If packing of both the salts is compared, it is apparent that $\mathrm{C}-\mathrm{H}$...F interactions are playing an important role in the lattice stabilization and fluorine atom is involved in $\mathrm{C}-\mathrm{H} \cdots \mathrm{F}-\mathrm{C} \quad(\mathrm{C} 12-\mathrm{H} 12 \mathrm{~A} \ldots$ $\mathrm{F} 1=2.423 \AA$ ) hydrogen bonds of comparable strength as $\mathrm{C}-\mathrm{H} \ldots \mathrm{O} \quad(\mathrm{C} 11-\mathrm{H} 11 \mathrm{~A} \ldots \mathrm{O} 6=2.657$, C12-H12A...O7 = 2.421 A) hydrogen bonds formed by oxygen atoms (strong hydrogen bond acceptor) of the $-\mathrm{NO}_{2}$ group in 2 . The strength of $\mathrm{C}-\mathrm{H} \cdots \mathrm{Cl}$ hydrogen bonds in both complexes 1 (C48$\mathrm{H} 48 \mathrm{~A} \ldots \mathrm{Cll}=2.907 \AA)$ and $2 \quad(\mathrm{C} 9-\mathrm{H} 9 \mathrm{~A} \ldots \mathrm{Cll}=$ $2 \cdot 837 \AA$ ) are almost the same.

\section{Conclusions}

The potential of weak second sphere interactions $(\mathrm{C}-\mathrm{H} \cdots \mathrm{F}$ and $\mathrm{C}-\mathrm{H} \cdots \mathrm{O})$ in the binding of $2,5-$ substituted carboxylates by cationic cobalt(III) complex $\left[\mathrm{Co}(\text { phen })_{2} \mathrm{CO}_{3}\right]^{+}$has been explored by isolating and characterizing the two new $\mathrm{Co}$ (III) complex salts, $\left[\mathrm{Co}(\text { phen })_{2} \mathrm{CO}_{3}\right]_{2}$ (2-chloro-5-fluorobenzoate). $11 \mathrm{H}_{2} \mathrm{O}$ (1) and $\left[\mathrm{Co}(\text { phen })_{2} \mathrm{CO}_{3}\right]$ (2-chloro-5-nitrobenzoate) $\cdot 6 \mathrm{H}_{2} \mathrm{O}(2)$. As laid down as an objective at 
the outset to evaluate $\mathrm{C}-\mathrm{H} \cdots \mathrm{F}$ interactions amid the presence of chloro group has shown that $\mathrm{C}-\mathrm{H} \cdots \mathrm{F}$ interactions can indeed manifest in complex $\mathbf{1}$. In addition, replacement of a fluoro group with a nitro group has profound effect in the packing arrangement as seen in the complex salt $\mathbf{2}$, still the complex has $\mathrm{C}-\mathrm{H} \cdots \mathrm{Cl}$ interactions along with large number of $\mathrm{C}-\mathrm{H} \cdots \mathrm{O}$ interactions. Comparison of the packing features of 1 and 2 shows that $\mathrm{C}-\mathrm{H} \cdots \mathrm{X}(\mathrm{X}=$ halogen $)$ interaction can manifest even in ionic compounds having a large number of hetero atom interactions like $\mathrm{O}-\mathrm{H} \cdots \mathrm{O}, \mathrm{C}-\mathrm{H} \cdots \mathrm{O}$ and $\pi-\pi$ stacking interactions. Thus, it is important to consider the cooperative interplay of weak second sphere interaction of the kind $\mathrm{C}-\mathrm{H} \cdots \mathrm{F}$ and $\mathrm{C}-\mathrm{H} \cdots \mathrm{Cl}$ even in ionic solids in which molecules are endowed with halogen $(\mathrm{F}$ and $\mathrm{Cl})$ substitution. Such consideration may facilitate the crystal engineering of this kind of ionic solids in which weak second sphere coordination has a marked influence even in the presence strong ionic interactions.

\section{Supplementary data}

Crystallographic data of the title complex salts have been deposited with the Cambridge Crystallographic Data Center allocated with the deposit number CCDC 748423 and 748424. Copy of the data can be obtained free of charge on application to CCDC, 12 Union Road, Cambridge CB2 1EZ, UK fax $(+44)$ 1223 336033, e-mail: deposit@ ccdc.cam.ac.uk.

\section{Acknowledgements}

This work was supported by the Council of Scientific and Industrial Research (CSIR) vide grant no 01(2020)2005/EMR-II and by the Thai Government Stimulus Package 2 (TKK2555), under the Project for the Establishment of a Comprehensive Centre for Innovative Food, Health Products and Agriculture (PERFECTA) and the Centre for Petroleum, Petrochemicals and Advanced Materials, Chulalongkorn University.

\section{References}

1. Purser S, Morre P R, Swallow S and Gouverneur V 2008 Chem. Soc. Rev. 37320

2. Graber D, Moroder $\mathrm{H}$ and Micura R $2008 \mathrm{~J}$. Am. Chem. Soc. 13017230

3. Curran D P, Mikami K and Soloshonok V A 2006 J. Fluorine Chem. 127454
4. Dolbier Jr W R and Prakash G K S 2008 J. Fluorine Chem. 129896

5. Taylor R and Kennard O 1982 J. Am. Chem. Soc. 104 5063

6. Desiraju G R and Parthasarathy R $1989 \mathrm{~J}$. Am. Chem. Soc. 1118725

7. Shimoni L, Carrell H L, Glusker J P and Coombs M M 1994 J. Am. Chem. Soc. 1168162

8. Weis H-C, Blaser D, Boese R, Nangia A and Desiraju G R 1998 J. Am. Chem. Soc. 1208702

9. Howard J A K, Hoy V J, O'Hagan D and Smith G T 1996 Tetrahedron $\mathbf{5 2} 12613$

10. Dunitz J D and Taylor R 1997 Chem. Eur. J. 389

11. Shimoni L and Glusker J P 1994 Struct. Chem. 3383

12. Prasanna M D and Guru Row T N 2000 Cryst. Eng. Comm. 2134

13. Choudhury A R, Urs. U K, Smith P S, Goddard R, Howard J A K and Guru Row T N $2002 \mathrm{~J}$. Mol. Struct. 641225

14. Weis H-C, Blaser D, Boese R, Nangia A and Desiraju G R 1999 Acta Cryst. B55 1005

15. Vangala V R, Nangia A and Lynch V M 2002 Chem. Commun. 1304

16. Choudhury A R, Bhat R G, Guru Row $\mathrm{T} N$ and Chandrasekaran S 2007 Cryst. Growth Des. 7844

17. D'Oria E and Novoa J J 2008 Cryst. Eng. Comm. 10 423

18. Sharma R P, Singh A, Brandão $P$, Félix V and Venugopalan P 2008 J. Mol. Struct. 892452

19. Sharma R P, Singh A, Brandão $P$, Félix V and Venugopalan P 2009 J. Mol. Struct. 921227

20. Singh A, Sharma R P, Ferretti V, Rossetti S and Venugopalan P 2009 J. Mol. Struct. 927111

21. Sharma R P, Singh A, Aree T and Venugopalan $P$ 2009 J. Mol. Struct. 92818

22. Singh A, Sharma R P, Aree T and Venugopalan $\mathrm{P}$ 2009 J. Fluorine. Chem. 130650

23. Forni A, Metrangolo P, Pilati P and Resnati G 2004 Cryst. Growth Des. 4291

24. Lommerse J P M, Stone A J, Taylor R and Allen F H 1996 J. Am. Chem. Soc. 1183108

25. Fontana F, Forni A, Metrangolo P, Panzeri W, Pilati T and Resnati G 2002 Supramol. Chem. 1447

26. Metrangolo P and Resnati G 2001 Chem. Eur. J. 7 2511

27. Walsh R B, Padgett C W, Metrangolo P, Resnati G, Hanks T W and Pennington W T 2001 Cryst. Growth Des. 1165

28. Legon A C 1999 Angew. Chem. Int. Ed. 382686

29. Jay J I, Padgett C W, Walsh R D B, Hanks T W and Pennington W T 2001 Cryst. Growth Des. 1501

30. Thaimattam R, Sharma C V K, Clearfield A and Desiraju G R 2001 Cryst. Growth Des. 1103

31. Garden S J, Fontes S P, Wardell J L, Skakle J M S, Low J N and Glidewell C 2002 Acta Cryst. $B 58701$

32. Fu X-C, Wang X-Y, Li M-T, Wang C-G and Deng X-T 2006 Acta Cryst. E62 m1263

33. Schlessinger G G 1967 Inorg. Synth. 9160

34. Bruker-Nonius 2006 APEX2, Version 2.0-2; Bruker AXS: Madison, WI, USA

35. Sheldrick G M 2008 Acta Cryst. A64 112 
36. Geary W J 1971 Coord. Chem. Rev. 781

37. Roh S-G, Oh J B, Nah M-K, Baek N S, Lee Y and Kim H K 2004 Bull. Korean Chem. Soc. 251503

38. Zehang X-D, Ge C-H, Zhang X-Y, Guo Y-N and Liu Q-T 2008 Russ. J. Coord. Chem. 34729

39. Ferenc W, Bocian B and Walków-Dziewulska A 2004 J. Therm. Anal. Cal. 76179

40. Nakamoto K 1997 Infrared and Raman spectra of inorganic and coordination compounds (New York: Wiley) 3rd edn

41. Nyquist R A and Kagel R O 1971 Infrared spectra of inorganic compounds (New York and London: Academic Press)

42. Silverstein R M and Webster F X 2006 Spectrometric identification of organic compounds (India: John Wiley and Sons) 6th edn, p. 288
43. Francis D J and Jordan R B 1972 Inorg. Chem. 11461

44. Niederhoffer E C, Martell A E, Rudolf P and Clearfield A 1982 Inorg. Chem. 213734

45. Thomas N C, Pringle K and Deacon G B 1989 J. Chem. Edu. 68516

46. Sugiyama T, Meng J-B and Matsuura T 2002 Acta Cryst. C58 o242

47. Tan T 2007 J. Mol. Struct. 8406

48. Ishida H, Rahman B and Kashino S 2001 Acta Cryst. C57 1450

49. Bernstein J, Davis R E, Shimon L and Chang N L 1995 Angew. Chem. Int. Ed. Engl. 341555

50. Etter M C 1990 Acc. Chem. Res. 23120

51. Etter M C 1991 J. Phys. Chem. 954601

52. Etter M C, MacDonald J C and Bernstein J 1990 Acta Cryst. B46 25 